\title{
MANAJEMEN KURIKULUM DAN PEMBELAJARAN \\ BERBASIS ICT
}

\author{
Sri Giarti \\ sgiarty@gmail.com \\ SD N 2 Bengle, Wonosegoro - Boyolali
}

\begin{abstract}
ABSTRAK
Penelitian ini bertujuan untuk mengetahui gambaran implementasi manajemen kurikulum dan pembelajaran berbasis ICT di SD serta kesenjangan yang terjadi. Jenis penelitian menggunakan penelitian deskriptif kualitatif. Lokasi penelitian dilakukan di SD Negeri 2 Bengle, Wonosegoro - Boyolali. Pelaksanaan penelitian ini dilakukan melalui tahapan penyusunan rancangan penelitian, pengumpulan data, analisis data dan penyusunan laporan penelitian. Instrumen pengumpalan data menggunakan lembar observasi dan wawancara serta lembar studi dokumen. Teknik analisa data menggunakan teknik deskriptif kualitatif. Hasil penelitian menunjukkan temuan bahwa terdapat kesenjangan dalam mengimplementasikan manajemen kurikulum dan pembelajaran, yaitu: 1) pada perencanaan, guru belum membuat RPP berbasis $I C T, 2)$ pada tahap pelaksanaan, guru belum semua menggunakan media pembelajaran berbasis $I C T$ dalam pembelajaran di kelas, hanya ada 3 guru yang menggunakan media berbasis $I C T, 3$ ) pada pengawasan, kepala sekolah belum rutin melakukan supervisi pembelajaran, evaluasi dan pelaporan. Selain kendala manajemen, masih ada kendala di luar manajemen yaitu 1) minimnya sarana prasarana, hanya tersedia 2 laptop dan 2 LCD sehingga pemakaiannya harus bergantian, selain itu belum ada akses internet karena letak sekolah berada di pinggiran; 2) rendahnya kompetensi guru masih rendah, dari 7 guru yang ada, hanya 3 guru yang mampu mengoperasikan komputer.
\end{abstract}

Kata kunci: manajemen, kurikulum dan pembelajaran, ICT

\section{PENDAHULUAN}

Kemajuan ilmu pengetahuan dan teknologi membawa dampak tersendiri bagi dunia pendi-dikan, dimana ilmu pengetahuan dan teknologi membantu proses pendidikan untuk menciptakan sistem pendidikan yang lebih komprehensif dan fleksibel sehingga para lulusan dapat berfungsi secara efektif dalam kehidupan masyarakat global. Melihat dampak yang ditimbulkan maka pendidikan harus dirancang sesuai dengan perkembangan ilmu pengetahuan sehingga dapat memungkinkan peserta didik mengembangkan potensi diri yang dimilikinya secara alami dan kreatif dalam suasana penuh kebebasan, kebersamaan dan tanggung jawab.
Pemerintah memberikan kebebasan kepada setiap sekolah untuk mengembangkan pembelajaran sesuai dengan kondisi dan karakteristik siswa dengan memberikan pedoman yang harus dijadikan dasar dalam mengembangkan pembelajaran. Hal ini sesuai dengan Undang-Undang Nomor 32 Tahun 2004 tentang Pemerintahan Daerah, menjelaskan bahwa sebagian besar kewenangan Pemerintah Pusat dilimpahkan kepada Pemerintah Daerah. Salah satu kewenangan yang dilimpahkan ialah kewenangan pendidikan. Pelimpahan ini dilandasi oleh perubahan paradigma penyelenggaraan pendidikan dari sentralistik menjadi desentralistik. Perubahan paradigma ini bermuara pada peningkatan mutu 
pendidikan di Indonesia sehingga memerlukan reorientasi penyelenggaraan pendidikan dari sentralistik menuju ke desentralistik. Sekolah harus mengembangkan pembelajaran sesuai dengan karakteristik masing-masing siswa dengan berpedoman pada peraturan pusat.

Undang-Undang Nomor 20 Tahun 2003 tentang Sistem Pendidikan Nasional menyebutkan bahwa kurikulum diartikan sebagai seperangkat rencana dan pengaturan mengenai tujuan, isi, dan bahan pembelajaran untuk mencapai tujuan pendidikan tertentu. Berpijak pada Undang-Undang Sisdiknas maka Kepala Sekolah sebagai pemimpin sekolah harus mampu mengelola pelaksanaan pembelajaran dengan baik sesuai dengan perkembangan jaman. Yakni pembelajaran yang dilaksanakan tidak berfokus pada guru saja atau konvensional namun dengan mampu mengaktifkan siswa oleh sebab itu pelaksanaan pembelajaran harus dapat memanfaatkan teknologi informatika komputer dengan demikian diharapkan pembelajaran dapat menarik dan meningkatkan motivasi siswa. Penerapan manajemen kurikulum dan pembelajaran berbasis $I C T$ yang baik diyakini dapat meningkatkan mutu pendidikan.

Namun pada kenyataannya masih jauh dari harapan, masih banyak sekolah-sekolah di Indonesia belum memanfaatkan sepenuhnya teknologi informatika komputer. Masih banyak guru-guru yang belum melek ICT selain itu guruguru beranggapan bahwa pembelajaran berbasis ICT sangat merepotkan. Sebagai pemimpin sekolah, Kepala Sekolah harus mampu menjadi manajer yang baik, dalam hal ini dapat mengelola manajemen kurikulum dan pembelajaran dengan baik yaitu dengan menerapkan manajemen kurikulum dan pembelajaran berbasis ICT pada setiap pembelajaran di kelas.

Berikut berbagai penelitian relevan tentang penerapan manajemen kurikulum dan pembelajaran berbasis ICT. Sri Intan Wahyuni (2009) melaporkan penelitian dengan judul Manajemen Kurikulum dalam Meningkatkan Mutu Pembelajaran PAI di MTs Negeri Laboratorium UIN Sunan Kalijaga Yogjakarta, penelitian ini menemukan bahwa, (a) implementasi manajemen kurikulum di MTs Negeri Laboratorium UIN Sunan Kalijaga meliputi: landasan dan tujuan manajemen kurikulum PAI yaitu pada tingkat sekolah dan tingkat kelas yang dikembangkan oleh masingmasing guru PAI dan penilaian kurikulum PAI dilakukan setelah proses belajar mengajar, (b) manajemen kurikulum dalam meningkatkan mutu pembelajaran PAI dengan melihat beberapa prinsip relevansi, prinsip fleksibilitas dan prinsip efektivitas.

Vivit Nur Arista Putra (2013) melakukan penelitian tentang Manajemen Pembelajaran Di Pondok Pesantren Takwinul Muballighin Yogyakarta, menemukan bahwa a) perencanaan pembelajaran secara prinsip dilengkapi silabus dan Rancangan Pelaksanaan Pembelajaran (RPP) tetapi belum didokumentasikan; b) pelaksanaan proses belajar mengajar menggunakan media pembelajaran seperti LCD, white board, spidol, dan makalah yang dibagikan kepada santri, e) Evaluasi pembelajaran menggunakan evaluasi formatifyaitu penilaian berupa tes yang dilakukan setelah satu pokok bahasan selesai dipelajari peserta didik dan evaluasi sumatif yaitu penilaian berupa tes yang dilaksanakan setelah proses belajar mengajar selesai dalam jangka waktu tertentu yaitu satu semester.

Nana Wulandari (2014) melaporkan penelitian dengan judul Manajemen Pembelajaran Berbasis Teknologi Informasi dan Komunikasi di SD Muhammadiyah Wirobrajan 3 Yogyakarta, penelitian ini menemukan bahwa SD Muhammadiyah Wirobrajan 3 Yogyakarta 
tergolong sekolah yang baru merintis pembelajaran berbasis Teknologi Informasi dan Komunikasi (TIK) karena pemanfaatan TIK masih terbatas penggunaan alat dan sebagai suplemen (tambahan) pembelajaran. Perencanaan pembelajaran melalui pembuatan RPP sesuai KTSP dengan prinsip menerapkan TIK yang terlihat dari komponen media/sumber belajar, misalnya internet dan komputer.

Penelitian tentang manajemen kurikulum, manajemen pembelajaran dan manajemen pembelajaran berbasis teknologi informasi dan komunikasi telah banyak dilakukan seperti telah dikemukakan pada review setiap jurnal, yaitu penelitian yang dilakukan oleh Sri Intan Wahyuni (2009), Vivit Nur Arista Putra (2013) dan Nana Wulandari (2014). Namun penelitianpenelitian yang dilakukan belum menghasilkan temuan mengenai manjemen kurikulum dan pembelajaran berbasis ICT dalam satu keilmuan atau masih terpisah-pisah sehingga itu berbeda dengan penelitian yang akan dilakukan oleh penulis.

Berpijak pada pentingnya manajemen kurikulum dan pembelajaran berbasis ICT dan berbagai penelitian mengenai manajemen kurikulum dan pembelajaran berbasis ICT maka penulis melakukan studi kasus di SD Negeri Kabupaten Boyolali untuk melihat gambaran mengenai implementasi manajemen kurikulum dan pembelajaran berbasis ICT .

Berdasarkan latar belakang seperti tersebut di atas, permasalahan penelitian yang akan dipecahkan adalah Bagaimana implementasi manajemen kurikulum dan pembelajaran berbasis ICT di SD Negeri Kabupaten Boyolali dan apa kesenjangan yang terjadi dalam upaya penerapan manajemen kurikulum dan pembelajaran berbasis $I C T$.

\section{KAJIAN PUSTAKA}

\section{Manajemen Kurikulum dan Pembelajaran Berbasis ICT}

Manajemen Kurikulum

Istilah manajemen berarti proses pengelolaan usaha yang dilaksanakan secara teratur untuk mencapai tujuan bersama. Sedangkan kurikulum merupakan seperangkat rancangan dan rencana pembelajaran yang digunakan sebagai alat dan cara untuk melakukan pembelajaran baik dalam lingkup formal, nonformal maupun informal untuk mencapai tujuan pendidikan nasional. Dengan demikian, manajemen kurikulum merupakan sebuah proses pengelolaan mengenai kurikulum yang dilakukan oleh sekelompok orang untuk meningkatkan kualitas pembelajaran dalam rangka mencapai tujuan kurikulum yang telah ditetapkan.

Simpulan mengenai manajemen kurikulum di atas sejalan dengan pendapat dari Tim Pengembang Ilmu Pendidikan FIP UPI (2007: 122), Arikunto dan Yuliana (2008: 131) serta Rusman (2011: 3) yang mengatakan bahwa manajemen kurikulum merupakan sistem pengelolaan kurikulum yang kooperatif, komprehensif, sistemik, dan sistematik yang dirancang untuk memudahkan pengelola pendidikan dalam melaksanakan kegiatan belajar mengajar melalui tahapan perencanaan, implementasi, evaluasi dan penyempurnaan program agar kegiatan belajar mengajar terarah dengan baik. Dari pendapat diatas dapat diinventarisasi mengenai komponen-komponen dalam manajemen kurikulum berikut; 1) perencanaan, 2) implementasi, 3) evaluasi, 4) penyempurnaan program.

Selanjutnya, Depdiknas (2000: 67) menyebutkan kegiatan dalam manajemen kurikulum yaitu: a) menjabarkan kompetensi lulusan menjadi analisis mata pelajaran, 
b) menyusun program tahunan, c) menyusun program semester, d) menyusun program satuan pelajaran, e) membuat rencana pengajaran, f) melakukan penbagian tugas mengajar, g) menyusun jadwal pelajaran, h) menyusun jadwal kegiatan pengayaan, i) menyusun jadwal ekstrakurikuler,j) menyusun jadwal penyegaran Guru.

Lebih lanjut, Jay Zigel (2012) menjelaskan tugas dalam manajemen kurikulum mencakup: (a) menyelenggarakan perumusan tentang tujuan-tujuan kurikulum; (b) menyelenggarakan inti (content), susunan (scope) dan organisasi kurikulum; (c) menghubungkan kurikulum dengan waktu, fasilitas-fasilitas fisik dan personil yang tersedia; (d) menyelenggarakan bahan-bahan, sumber-sumber dan perlengkapan buat program pengajaran; (e) menyelenggarakan supervisi pengajaran.

Berpijak dari pengertian, prosedur, kegiatan dan tujuan manajemen kurikulum menurut hikmah penulis dapat disimpulkan bahwa pengelolaan manajemen kurikulm yang baik tergantung pada pengelola program yaitu kepala sekolah dan guru-guru dalam menjabarkan isi kurikulum secara lebih rinci dan operasional ke dalam program tahunan, dan semesteran sehingga menghasilkan kurikulum melalui kegiatan perencanaan, perencanaan, implementasi, evaluasi dan penyempurnaan program sehingga sesuai dengan tujuan yang hendak dicapai.

\section{Manajemen Pembelajaran}

Manajemen pembelajaran merupakan kemampuan guru dalam mendayagunakan sumber daya yang ada, melalui kegiatan menciptakan dan mengembangkan kerja sama, sehingga terbentuk pembelajaran secara efektif dan efisien. Alben Ambarita dan Suryosubroto, seperti dikutip oleh Asep Suhendi Arifin (2013) menjelaskan bahwa kegiatan manajemen pembelajaran ialah membuat perencanaan pembelajaan, melakukan pelaksanaan terhadap proses pembelajaran, melakukan pemantauan dan melakukan penilaian sebagai evaluasi terhadap pembelajaran yang telah dilakukan: (a) perencanaan pembelajaran, merupakan kegiatan awal yang dilakukan guru dalam menyusun materi pengajaran, metode mengajar, melengkapi media pengajaran dan menentukan porsi waktu untuk mencapai tujuan yang telah ditetapkan Degeng (1993: 2), Alben Ambarita (2006: 73). Kegiatan tersebut meliputi; (1) penyusunan silabus, program tahunan, program semester, dan mid semester, (2) penyusunan desain pembelajaran peserta didik, (3) penguasaan dan implementasi metode pembelajaran, (4) penilaian sebagai uji kompetensi, (5) kontrol dalam pencapaian indikator keberhasilan peserta didik. Selanjutnya, Mulyasa (2006: 176) mengatakan bahwa Rencana Pelaksanaan Pembelajaran (RPP) merupakan bagian dari perencanaan pembelajaran. RPP adalah rencana yang menggambarkan prosedur dan manajemen pembelajaran untuk mencapai satu atau lebih kompetensi dasar yang ditetapkan dalam standar isi dan dijabarkan silabus; (b) Pelaksanaan Pembelajaran merupakan suatu kegiatan yang bernilai edukatif mewarnai interaksi yang terjadi antara guru dan siswa. Interaksi yang bernilai edukatif dikarenakan pelaksanaan pembelajaran yang dilakukan diarahkan untuk mencapai tujuan tertentu yang telah dirumuskan sebelumnya (Syaiful Bahri, Aswan Zain (2010: 1) dan Nana Sudjana (2010: 136); (c) Evaluasi pembelajaran, merupakan pembelajaran adalah rangkaian kegiatan yang dilakukan untuk mengetahui seberapa tinggi tingkat keberhasilan. Kegiatan tersebut meliputi; mengumpulkan, menganalisis dan menginterpretasi informasi secara sistematik untuk mencapai tujuan pembelajaran. (Grondlund dan Linn (1990: 5) 


\section{Pembelajaran Berbasis ICT}

\section{Information and Communication} Technology (ICT) dalam konteks bahasa Indonesia disebut Teknologi Informasi dan Komunikasi (TIK). Pembelajaran berbasis ICT pada dasarnya merupakan pemanfaatan teknologi informasi dan komunikasi untuk menunjang proses pembelajaran agar dapat mencapai tujuan yang telah dirumuskan. Kementrian Pendidikan dan Kebudayaan (Tim, 2011: 4) menjelaskan definisi pembelajaran berbasis teknologi informasi dan komunikasi secara konseptual sebgai pembelajaran tatap muka dengan dukungan teknologi informasi dan komunikasi yang memfasilitasi siswa sebagai penyampai materi maupun sebagai tutor menggunakan konten digital. Secara operasional, pembelajaran berbasis ICT merupakan aktivitas pembelajaran yang didukung infrastruktur teknologi informasi dan komunikasi, menggunakan aplikasi dan aturan pengelolaan pembelajaran, serta konten digital yang merupakan bahan pengayaan pembelajaran tatap muka di kelas.

Manajemen pembelajaran berbasis ICT merupakan bagaimana perencanaan pembelajaran itu dilakukan, bagaimana pengorganisasian pembelajaran, bagimana pembelajaran itu dilaksanakan dan bagaimana mengevaluasi pembelajaran menggunakan ICT sebagai media pembelajaran. Media pembelajaran berbasis ICT ini menyediakan: 1) konten instruksional yang bersifat prosedural, deklaratif serta terdefinisi dengan baik dan jelas; 2) konten yang bersifat learner-centered yaitu konten yang menyajikan hasil (outcomes) dari instruksional yang terfokus pada pengembangan kreatifitas dan memaksimalkan kemandirian; 3) contoh kerja (work example) pada material konten untuk mempermudah pemahaman dan memberikan kesempatan untuk berlatih; 4) menambahkan konten berupa games edukatif sebagai media berlatih alat bantu pembuatan pertanyaan.

Gambaran mengenai pembelajaran berbasis ICT seperti dipaparkan di atas nampak, bahwa melalui media pembelajaran seperti ini pembelajaran tidak berpusat pada guru namun siswa dapat belajar mencari tahu sendiri materi yang berhubungan dengan topik yang disajikan, dengan demikian pembelajaran ini mampu mengembangkan kreativitas siswa dan kemandirian siswa dalam belajar.

\section{Manajemen Kurikulum dan Pembelajaran Berbasis ICT}

Seperti telah dipaparkan pada bagian terdahulu mengenai manajemen kurikulum, manajemen pembelajaran dan pembelajaran berbasis ICT maka dapat ditarik simpulan, bahwa manajemen kurikulum berbasis ICT merupakan sistem pengelolaan kurikulum yang dirancang untuk memudahkan guru dalam mendayagunakan sumber daya yang ada, melalui kegiatan menciptakan dan mengembangkan kerja sama, sehingga terbentuk pembelajaran secara efektif dan efisien menggunakan media pembelajaran multimedia atau ICT.

Manajemen kurikulum dan pembelajaran berbasis ICT merupakan kegiatan yang bertujuan untuk meningkatkan mutu pendidikan yang mengacu pada standar kelulusan, standar isi, standar proses dan standar penilaian dengan demikian diharapkan peserta didik mempunyai kebebasan berpikir melalui aktivitas intelektual sampai mencapai pemahaman konsep yang tidak sebatas materi yang diberikan guru.

Tim Direktorat Pembina Sekolah Dasar (2014:38) menyebutkan mengenai ruang lingkup dalam manajemen kurikulum dan pembelajaran yaitu:(1)perencanaan/penyusunan RPP, (2) penyusunan kalender sekolah, (3) 
pembagian tugas mengajar dan penyusunan jadwal mengajar, (4) pelaksanaan pembelajaran, (5) penilaian pembelajaran, (6) pengawasan melalui sipervisi pembelajaran, (7) penyusunan peraturan akademik, (8) penentuan beban belajar, (9) pemilihan pendekatan saintifik dan strategi PAKEM, (10) pengawasan dan evaluasi serta laporan. Berikut akan dibahas lebih lanjut mengenai ruang lingkup manajemen kurikulum dan pembelajaran

Secara visual Gambar 1, menggambarkan pemetaan proses ruang lingkup manajemen kurikulum dan pembelajaran berbasis $I C T$.

\section{METODE}

Jenis penelitian menggunakan penelitian deskriptif kualitatif. Penelitian kualitatif ini dilakukan di SD Negeri 2 Bengle, Wonosegoro - Boyolali Tahun Pelajaran 2016/2017. Pelaksanaan penelitian dilakukan melalui tahapan penyusunan rancangan penelitian, pengumpulan data, analisis data dan penyusunan laporan penelitian. Instrumen pengumpalan data menggunakan lembar observasi dan wawancara serta lembar studi dokumen. Teknik analisa data menggunakan teknik deskriptifkualitatif.

\section{HASIL DAN PEMBAHASAN}

SD Negeri 2 Bengle, Wonosegoro Boyolali didirikan pada tahun 1978, diasuh oleh 7 guru yaitu 4 guru berstatus negeri dan 3 orang guru berstatus wiyata bakti. Berdasarkan observasi dan wawancara dengan Kepala Sekolah dan guru mengenai proses manajemen kurikulum dan pembelajaran berbasis $I C T$, dapat dipetakan proses manajemen dan pembelajaran berbasis ICT. Tabel 1 menunjukkan pemetaan proses manajemen dan pembelajaran tersebut.

\section{METODE}

Jenis penelitian menggunakan penelitian deskriptif kualitatif. Penelitian kualitatif ini dilakukan di SD Negeri 2 Bengle, Wonosegoro - Boyolali Tahun Pelajaran 2016/2017. Pelaksanaan penelitian dilakukan melalui tahapan penyusunan rancangan penelitian, pengumpulan data, analisis data dan penyusunan laporan

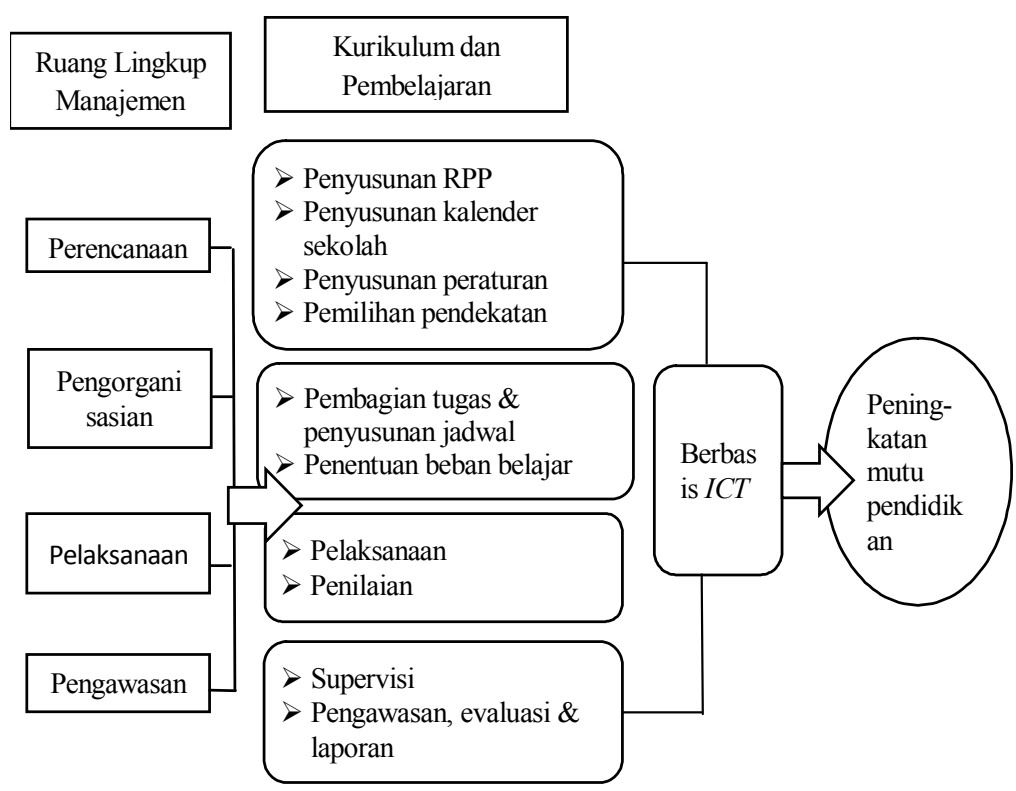

Gambar 1 Manajemen Kurikulum dan pembelajaran Berbasis ICT 
penelitian. Instrumen pengumpulan data menggunakan lembar observasi dan wawancara serta lembar studi dokumen. Teknik analisa data menggunakan teknik deskriptif kualitatif.

\section{HASIL DAN PEMBAHASAN}

SD Negeri 2 Bengle, Wonosegoro Boyolali didirikan pada tahun 1978, diasuh oleh 7 guru yaitu 4 guru berstatus negeri dan 3 orang guru berstatus wiyata bakti. Berdasarkan observasi dan wawancara dengan Kepala Sekolah dan guru mengenai proses manajemen kurikulum dan pembelajaran berbasis $I C T$, dapat dipetakan proses manajemen dan pembelajaran berbasis ICT. Tabel 1 menunjukkan pemetaan proses manajemen dan pembelajaran tersebut.

Dari Tabel 1, nampak bahwa proses:

a) Perencanaan, guru belum membuat RPP berbasis $I C T$, guru hanya menggunakana RPP cetak yang sudah ada jadi dalam RPP tersebut tidak mengkombinasikan media berbasis ICT, pada awal tahun pelajaran guru sudahmenyusun kalender sekolah yang dituang dalam program tahunan dan program semester selanjutnya kepala sekolah juga sudah menyusun kalender

Tabel 1 Pemetaan Proses Manajemen dan Pembelajaran

\begin{tabular}{|c|c|c|c|}
\hline No & Proses & Komponen & Indikator esensial \\
\hline \multirow{4}{*}{1} & \multirow{4}{*}{$\begin{array}{l}\text { Peren- } \\
\text { canaan }\end{array}$} & $\begin{array}{l}\text { Penyusunan RPP } \\
\text { berbasis } I C T\end{array}$ & $\begin{array}{l}\text { Guru belum membuat RPP berbasis } I C T \\
\text { hanya menggunakan RPP yang sudah jadi }\end{array}$ \\
\hline & & $\begin{array}{l}\text { penyusunan } \\
\text { kalender sekolah }\end{array}$ & $\begin{array}{l}\text { Guru menyusun kalender sekolah yang } \\
\text { dituang dalam program tahunan, program } \\
\text { semester }\end{array}$ \\
\hline & & $\begin{array}{l}\text { Penyusunan } \\
\text { peraturan }\end{array}$ & $\begin{array}{l}\text { Kepala Sekolah menyusun peraturan } \\
\text { mengenai: persyaratan kehadiran, ketentuan } \\
\text { ulangan, ujian sekolah dan remedial dan } \\
\text { pengayaan, kenaikkan kelas, kelulusan, dan } \\
\text { hak-hak lainnya bagi siswa }\end{array}$ \\
\hline & & $\begin{array}{l}\text { Pemilihan } \\
\text { pendekatan dan } \\
\text { strategi }\end{array}$ & $\begin{array}{l}\text { Belum semua guru menggunakan model } \\
\text { pembelajaran PAKEM menggunakan media } \\
\text { berbasis } I C T \text {. Ada } 3 \text { guru yang sudah } \\
\text { menggunakan media berbasis ICT dalam } \\
\text { bentuk PPT. }\end{array}$ \\
\hline \multirow{3}{*}{2} & \multirow{3}{*}{$\begin{array}{l}\text { Peng- } \\
\text { organi- } \\
\text { sasian }\end{array}$} & $\begin{array}{l}\text { Pembagian tugas } \\
\text { dan penyusunan } \\
\text { jadwal }\end{array}$ & $\begin{array}{l}\text { Kepala sekolah membuat SK pembagian } \\
\text { Tugas sesuai dengan keahlian masing-masing } \\
\text { guru. }\end{array}$ \\
\hline & & & $\begin{array}{l}\text { Kepala Sekolah menyusun jadwal pelajaran } \\
\text { disesuaikan dengan waktu pertemuan }\end{array}$ \\
\hline & & $\begin{array}{l}\text { Penentuan beban } \\
\text { mengajar }\end{array}$ & $\begin{array}{l}\text { Kepala Sekolah menentukan beban mengajar } \\
\text { berdasarkan kurikulum yang berlaku } \\
\text { misalnya guru kelas mengajar minimal } 24 \\
\text { jam. }\end{array}$ \\
\hline \multirow[b]{2}{*}{3} & \multirow[b]{2}{*}{$\begin{array}{l}\text { Pelak- } \\
\text { sanaan }\end{array}$} & $\begin{array}{l}\text { Pelaksanaan } \\
\text { pembelajaran }\end{array}$ & $\begin{array}{l}\text { Guru dalam mengajar belum semua } \\
\text { menggunakan media berbasis } I C T \text {, hanya } 3 \\
\text { guru yang memanfaatkan ICT }\end{array}$ \\
\hline & & $\begin{array}{l}\text { Penilaian } \\
\text { pembelajaran }\end{array}$ & $\begin{array}{l}\text { Guru sudah melakukan penilaian baik } \\
\text { harian, ulangan tengah semester, akhir } \\
\text { semester dan kenaikan kelas. } \\
\text { Setelah melakukan ulangan harian guru } \\
\text { menganalisa hasil penilaian untuk } \\
\text { menentukan siswa yang tuntas atau belum } \\
\text { tuntas. Bagi siswa yang belum tuntas } \\
\text { dilakukan remedial sedangkan bagi siswa } \\
\text { yang belum tuntas dilakukan pengayaan }\end{array}$ \\
\hline \multirow[t]{2}{*}{4} & \multirow[t]{2}{*}{$\begin{array}{l}\text { Penga- } \\
\text { wasan }\end{array}$} & $\begin{array}{l}\text { Supervisi } \\
\text { pembelajaran }\end{array}$ & $\begin{array}{l}\text { Kepala Sekolah belum rutin melakukan } \\
\text { supervisi kepada guru, supervisi yang } \\
\text { dilakukan hanya setiap akhir semester. }\end{array}$ \\
\hline & & $\begin{array}{l}\text { Pengawasan dan } \\
\text { evaluasi serta } \\
\text { pelaporan }\end{array}$ & $\begin{array}{l}\text { Kepala sekolah sudah melakukan } \\
\text { pengawasan, evaluasi serta laporan }\end{array}$ \\
\hline
\end{tabular}


sekolah yang tertuang dalam program tahunan dan program semester, serta menyusun peraturan tentang persyaratan kehadiran, ketentuan ulangan, ujian sekolah dan remedial dan pengayaan, kenaikkan kelas, kelulusan, dan hak-hak lainnya bagi siswa, namun masih ada guru yang belum memilihmenggunakan model pembelajaran PAKEM menggunakan media berbasis ICT dikarenakan guru malas untuk membuat persiapan hanya 3 guru yang menggunakan media berbasis ICT dalam bentuk PPT.

b) Pengorganisasian sudah dilakukan dengan baik, kepala sekolah sudah membuat pembagian tugas mengajar dan menyusun jadwal pelajaran yang disesuaikan dengan waktu pertemuan selain itu kepala sekolah juga sudah menentukan beban mengajar guru sesuai dengan kurikulum yang berlaku yaitu minimal 24 jam perminggu.

c) Pelaksanaan manjemen kurikulum dan pembelajaran berbasis ICT masih belum dilakukan dengan baik, hal ini nampak bahwa hanya 3 guru yang menggunakan media pembelajaran berbasis ICT dalam pembelajaran di kelas, ada 4 guru yang sama sekali tidak menggunakan media berbasis $I C T$. Sedangkan untuk penilaian pembelajaran, guru sudah melakukan penilaian baik harian, ulangan tengah semester, akhir semester dan kenaikan kelas, diakhir penilaian guru sudah menganalisa hasil penilaian untuk menentukan siswa yang tuntas atau belum tuntas. Bagi siswa yang belum tuntas dilakukan remedial sedangkan bagis siswa yang belum tuntas dilakukan pengayaan.

d) Pengawasan belum dilakukan dengan baik oleh kepala sekolah. Supervisi dilakukan hanya diakhir semester sehingga guru tidak mendapatkan pengarahan dalam pelaksanaan pembelajaran menggunakan media berbasis ICT selanjutnya kepala sekolah telah melakukan evaluasi serta laporan disetiap akhir semester.

Dari hasil observasi di atas terindikasi adanya gap/kesenjangan. Kesenjangan adalah sebuah permasalahan yang harus dipecahkan. Berdasarkan tabel 1, nampak adanya kesenjangan pada manajemen kurikulum dan pembelajaran berbasis ICT, yaitu: 1) Perencanaan, kesenjangan yang terjadi adalah guru belum membuat RPP berbasis ICT. 2) pelaksanaan, kesenjangan yang terjadi adalah bahwa guru belum menggunakan media pembelajaran berbasis ICT dalam pembelajaran di kelas. 3) pengawasan, kesenjangan yang terjadi adalah kepala sekolah tidak rutin melakukan supervisi pembelajaran, evaluasi dan pelaporan. Supervisi, evaluasi dan pelaporan hanya dilakukan satu kali diakhir semester hal ini berdampak pada pembelajaran, dalam mengajar guru tidak menggunakan media berbasis ICT sehingga pembelajaran hanya monoton .

Selain kendala manajemen di atas, masih ada kendala di luarmanajemen yaiu(1)minimnya sarana prasarana, SD hanya memiliki 2 laptop dan 2 LCD sehingga pemakaiannya harus bergantian selain itu belum ada akses internet karena letak SD berada di pinggiran; (2) rendahnya kompetensi guru masih rendah terbukti dari 7 guru yang ada, hanya 3 guru yang mampu mengoperasikan komputer.

\section{SIMPULAN DAN REKOMENDASI}

\section{Simpulan}

Berdasarkan hasil penelitian dan pembahasan, dapat disimpulkan bahwa pelaksanaan program manajemen kurikulum dan pembelajaran di SD Negeri 2 Bengle, Wonosegoro Boyolali terindikasi adanya kesenjangan, kesenjangan yaitu: 1) Perencanaan, 
kesenjangan yang terjadi adalah guru belum membuat RPP berbasis ICT.2) pelaksanaan, kesenjangan yang terjadi adalah bahwa guru belum menggunakan media pem-belajaran berbasis ICT dalam pembelajaran di kelas. 3) pengawasan, kesenjangan yang terjadi adalah kepala sekolah tidak rutin melakukan supervisi pembelajaran, evaluasi dan pelaporan. Supervisi, evaluasi dan pelaporan hanya dilakukan satu kali diakhir semester hal ini berdampak pada pembelajaran, dalam mengajar guru tidak menggunakan media berbasis ICT sehingga pembelajaran hanya monoton.

Selain faktor manajemen seperti dipaparkan di atas, ada juga faktor lain yang menjadi kendala dalam implementasi manajemen kurilukum dan pembelajaran berbasis ICT di SD ini yaitu; (1) minimnya sarana prasarana, SD hanya memiliki 2 laptop dan 2 LCD sehingga pemakaiannya harus bergantian selain itu belum ada akses internet karena letak SD berada di pinggiran; (2) rendahnya kompetensi guru bahwa masih rendah, terbukti dari 7 guru yang ada, hanya 3 guru yang mampu mengoperasikan komputer.

\section{Rekomendasi}

Rekomendasi yang diajukan dalam penelitian ini adalah; 1) sebaiknya kepala sekolah mengadakan pelatihan pengoperasian komputer dalam membuat media pembelajaran, 2) sebaiknya kepala sekolah menganggarkan pembelian laptop atau komputer dan LCD dari dana alokasi dan BOS, 3) sebaiknya kepala sekolah melakukan pembinaan kepada guru agar membuat perencanaan pembelajaran berbasis $I C T$, melaksanakan pembelajaran menggunakan media berbasis $I C T, 4$ ) sebaiknya kepala sekolah mengadakan evaluasi melalui program supervisi dan dilakukan secara rutin mengenai pelaksanaan kurikulum dan pembelajaran berbasis ICT.

\section{DAFTAR PUSTAKA}

Alben Ambarita. 2006. Manajemen Pembelajaran. Jakarta:Departemen Pendidikan Nasional.

Arikunto dan Yuliana. 2008. Manajemen Pendidikan. Yogyakarta: Aditya Media.

Asep Suhendi Arifin. 2013. Konsep Dasar Manajemen. Diakses dari http:// www.lpmpjabar.go.id/?q=node/330 pada tanggal 1 Juli 2016.

Gronlund, Norman E. dan Joyce E, Linn. 1990. Measurement and Evaluation in Teaching. New Jersey: Mcmillan Publishing Company

Jay Zigel. 2012. Manajemen Berbasis Sekolah (MBS). http://zigeljay.blogspot. co.id/2012/08/manajemen-berbasissekolah-mbs.html

Mulyasa . 2004. Manajemen berbasis sekolah Konsep, Strategi dan Implementasi. Bandung: Remaja Rosdakarya.

Mulyasa. 2006. Kurikulum Tingkat Satuan Pendidikan. Bandung: PT Remaja Rosdakarya.

Nana Sudjana. 2010. Dasar-Dasar Proses Belajar Mengajar. Bandung: Sinar Baru Algensindo.

Nana Wulandari. 2014. Manajemen Pembelajaran Berbasis Teknologi Informasi dan Komunikasi di SD Muhammadiyah Wirobrajan 3 Yogyakarta. FKIP PGSD Universitas Yogyakarta.

Oemar Hamalik. 2007. Manajemen Pengembangan Kurikulum. Bandung: Remaja Rosdakarya.

Pengembang Ilmu Pendidikan FIP UPI. 2007. Ilmu \&Aplikasi Pendidikan bagian 2 Ilmu Pendidikan Praktis. Bandung: UPI. 
Rusman. 2011. Manajemen Kurikulum. Jakarta: Rajawali Press.

Rusman. 2013. Belajar dan Pembelajaran Berbasis Komputer. Bandung: Alfabeta.

Sri Intan Wahyuni. 2009. Manajemen Kurikulum dalam Meningkatkan Mutu Pembelajaran PAI di MTs Negeri Laboratorium UIN Sunan Kalijaga Yogjakarta. Kependidikan Islam Universitas Islam Negeri Sunan Kalijaga Yogyakarta.

Suharsimi Arikunto. 2005. Dasar-Dasar Evaluasi Pendidikan. Jakarta: PT Bumi Aksara.

Syaiful Bahri \& Azwan Zain. 2010. Setrategi Belajar Mengajar. Jakarta: Rineka.
Tim Direktorat Pembinaan Sekolah Dasar. 2014. Panduan Pembinaan Manajemen Berbasis Sekolah di Sekolah Dasar. Jakarta: Kementerian Pendidikan dan Kebudayaan Direktorat Pendidikan dan Pembinaan Sekolah Dasar.

Undang-Undang Nomor 20 Tahun 2003 tentang Sistem Pendidikan Nasional Jakarta: Depdiknas.

Undang-Undang Nomor 32 Tahun 2004 tentang Pemerintahan Daerah. Jakarta: Depdiknas.

Vivit Nur Arista Putra. 2013. Manajemen Pembelajaran Di Pondok Pesantren Takwinul Muballighin Yogyakarta. Yogyakarta: FKIP Administrasi Pendidikan Universitas Negeri Yogyakarta. 